\title{
Application of essential oils in plant protection against pest insects - paper review
}

\author{
Zastosowanie olejków eterycznych w ochronie roślin \\ przed szkodnikami w świetle najnowszej literatury
}

\author{
Agnieszka Dutka
}

\section{Summary}

Essential oils based on volatile compounds have not been commonly used in plant protection. Taking into consideration the modern pest management, especially organic crop protection, essential oils could be a good alternative for traditional pest management against plant pathogens and pests. The aim of the study was to review the information on biological activities of essential oils against pest insects. Adequate choice of aroma and the concentration of essential oils allow to protect crops effectively.

Key words: essential oils, aphids, thrips and spider mites

\section{Streszczenie}

Olejki eteryczne stanowiące esencje zapachu roślin, nie są szeroko rozpowszechnione w ochronie roślin. W nowoczesnej ochronie roślin szczególnie w uprawach ekologicznych stanowią one dobrą alternatywę dla tradycyjnych środków ochrony roślin przeciw szkodnikom, chorobom i chwastom. Celem pracy było zebranie informacji na temat ich działania na szkodniki. Dobór odpowiednich zapachów i stężeń pozwala na skuteczną ochronę roślin uprawnych.

Słowa kluczowe: olejki eteryczne, mszyce, wciornastki i przędziorki

Instytut Hodowli i Aklimatyzacji Roślin - Państwowy Instytut Badawczy

Zakład Nasiennictwa i Ochrony Ziemniaka

76-009 Bonin 3

dutka83@wp.pl 


\section{Wstęp / Introduction}

Od chwili przystapienia do Unii Europejskiej w Polsce systematycznie spada liczba zarejestrowanych środków ochrony roślin, jak i liczba dostępnych substancji czynnych. Zmiany na liście środków ochrony roślin wynikają z priorytetów ochrony środowiska nad poprawą poziomu produkcji rolnej. Stosowanie środków ochrony, wiąże się z dużym ryzykiem, gdyż pomimo, że środek jest dopuszczony do stosowania nadal prowadzi się badania tych preparatów. Unia Europejska dokonała przeglądu około 1000 substancji stosowanych w środkach ochrony roślin pod kątem ich bezpieczeństwa dla ludzi, zwierząt i środowiska naturalnego. W wyniku tego przeglądu 74\% substancji czynnych została wycofana (Matyjaszczyk 2009).

Dla rolnictwa faktem alarmującym jest poważny spadek pszczół. Wyniki badań naukowych wskazują, że przyczyną wymierania pszczół może być stosowanie toksycznej grupy pestycydów - neonikotynoidów. Udowodniono, że w czterech krajach europejskich, które zakazały stosowania tych chemikaliów (Cummins 2007; American bee emergency - act now 2011) liczba pszczół gwałtownie wzrosła.

O ekologicznej i ludzkiej katastrofie w Argentynie, jednym $\mathrm{z}$ głównych producentów GM-soi na świecie, doniosło w kwietniu 2004 roku czasopismo naukowe „New Scientist”, gdzie stwierdzono, że utrata skuteczności pestycydów zmusza tam rolników do stosowania ich mieszanek o zwielokrotnionej toksyczności, a wynikiem jest rosnąca zapadalność na alergie i choroby dróg oddechowych wśród ludności wiejskiej oraz pracowników rolnych, a także obserwuje się coraz liczniejsze defekty płodów u ptaków (Branford 2004).

Zapotrzebowanie na ekologiczne środki ochrony roślin jest duże. Zarejestrowane są 22 środki przeznaczone do rolnictwa ekologicznego, z czego mniej do ochrony upraw rolniczych. W ostatnich latach rośnie zainteresowanie możliwościami zastosowania w ochronie roślin preparatów pochodzenia naturalnego, opartych na olejkach eterycznych (Górski i Piątek 2008).

Olejki eteryczne stanowią esencję zapachu roślin. Występują we wszystkich ich częściach, owocach, liściach i organach podziemnych, a nawet w pniu drzew (np. sosny, kamforowca). Sa to złożone chemicznie mieszaniny substancji naturalnych produkowanych przez roślinę dla jej własnych potrzeb. W ich skład wchodzi nawet do 150 różnorodnych związków. Spośród nich kilka najważniejszych grup to: terpeny (np. pinen w olejku sosnowym), alkohole (np. linalol w kolendrze), estry (np. octan linalolu w lawendzie), fenole (np. eugenol w goździkach), etery (np. anetol w owocach anyżu) (Ożarowski i Jaroniewski 1987).

Olejki eteryczne często spełniają funkcję naturalnych herbicydów i pestycydów. Ich działanie toksyczne w stosunku do różnych stadiów rozwojowych szkodników patogenów stwierdził między innymi Brud i Konopacka (1994), a właściwości repelentne na szkodniki i ich wpływ na obniżenie płodności owadów wykazali Regnault (1997) oraz Tunc i Sahinkaya (1998).

W nowoczesnej ochronie roślin, szczególnie upraw ekologicznych, mogą być one dobrą alternatywą dla tradycyjnych środków ochrony roślin. Od wielu lat poszukiwane są związki, które mogłyby skutecznie chronić rośliny np. przed mszycami.

\section{Przykłady zastosowań na mszycach Examples of application on aphids}

Hori (1998) badając w warunkach laboratoryjnych skuteczność 13 olejków na Myzus persicae Sulz., stwierdził wysoką repelentność olejku rozmarynowego oraz tymiankowego, które działały już w dawce $1 \mu \mathrm{l}$ na $40 \mu \mathrm{l}$ roztworu acetonu. W stężeniu $10 \mu \mathrm{l}$ działanie repelentne na mszycę brzoskwiniową wykazały olejki m.in. rozmarynowy, tymiankowy, z mięty pieprzowej, lawendowy oraz z mięty polnej. Hori (1999) w badaniach polowych $z$ olejkiem rozmarynowym i imbirowym, którymi nasączone były liny lub kulki winylowe, rozmieszczone wokół poletek tytoniu stwierdził, że bardziej skuteczny okazał się olejek rozmarynowy. W tym czasie wyłowiono z żółtych szalek 37\% mniej mszyc z poletek otoczonych liną nasączoną olejkiem rozmarynowym i $31 \%$, gdy poletko chroniono przy użyciu kulek winylowych. Chiasson i wsp. (2004) oceniając skuteczność zwalczania $M$. persicae przy użyciu olejku z komosy piżmowej stwierdzili, że ma on działanie toksyczne na mszyce już w stężeniu 0,5\%. Skuteczność działania tego olejku była również większa niż z miodli indyjskiej. Śmiertelność mszyc po zastosowaniu olejku z komosy piżmowej $\mathrm{w}$ stężeniu $0,5 \%$ po $24 \mathrm{~h}$ wyniosła $43 \%$, a na obiektach kontrolnych bez ochrony zaledwie 7\%. W przypadku ochrony olejkiem z miodli indyjskiej śmiertelność wyniosła 31\%, przy stężeniu 0,7\%. Digilioa i wsp. (2008) badali wpływ olejków eterycznych uzyskanych z 12 roślin występujących w klimacie śródziemnomorskim na zwalczanie mszyc. Stwierdzili, że jedynie po zastosowaniu olejków otrzymanych z biedrzeńca, anyżu, bazylii i kopru włoskiego, śmiertelność mszycy grochowianki (Acyrthosiphon pisum Harris) i mszycy brzoskwiniowej była duża. W badaniach przeprowadzonych przez Górskiego i Piątek (2009) stwierdzono 100\% śmiertelność mszycy ziemniaczanej (Aulacorthum solani Kalt.) po upływie $24 \mathrm{~h}$ od zastosowania olejków: lawendowego (Lavendula officinalis Chix) w stężeniu 0,02\%, geraniowego (Geranium L.) w stężeniu $0,05 \%$, z mięty pieprzowej (Mentha piperita L.) w stężeniu $0,05 \%$, sosnowego (Pinus silvestris L.) w stężeniu $0,1 \%$ oraz po $48 \mathrm{~h}$ olejku tymiankowego (Thymus vulgaris L.) w stężeniu 0,1\%. Było to doświadczenie laboratoryjne i polegało na zanurzeniu liścia tytoniu w przygotowanym roztworze olejków eterycznych. W późniejszych badaniach Górski i Kania (2010) wykazali również skuteczne działanie w zwalczaniu $A$. solani olejku kolendrowego (Coriandrum sativum) oraz olejku petitgrain otrzymanego z liści drzewa pomarańczy gorzkiej (Citrus aurantium var. amara). Stwierdzona śmiertelność owada była wysoka i zależna od stężenia. Po 72 godzinach od aplikacji śmiertelność po zastosowaniu olejku kolendrowego wyniosła 81,2-99,5\%, zaś skuteczność olejku petitgrain 89,8-99,5\%. Równie skuteczny w zwalczaniu A. solani na oberżynie był olejek cytronelowy i paczulowy w stężeniu 0,05 i $0,10 \%$ oraz jałowcowy w stężeniu $0,10 \%$. 
$100 \%$ skuteczność stwierdzono po 72 godzinach od aplikacji. Zdecydowanie słabsze działanie wykazały olejki: eukaliptusowy i bazyliowy. Olejek eukaliptusowy okazał się bardziej skuteczny w zwalczaniu mszycy ogórkowej (Aphis gossypii Glover) (Mareggiani i wsp. 2008). Po jednej godzinie w zależności od rozcieńczeń olejku uzyskano śmiertelności mszyc na poziomie 55-100\%. Po 24 godzinach śmiertelność po zastosowaniu niższych stężeń wyraźnie wzrastała (84-100\%). Olejek z konopi siewnej (Cannabis sativa L.) skutecznie ograniczał mszyce jabłoniowo-babkowe (Dysaphis plantaginea Pass.) występujące na jabłoni (Górski i wsp. 2009) do tego stopnia, że już w stężeniu 0,05 i $0,1 \%$ jego skuteczność była porównywalna ze skutecznością insektycydu Mospilan 20 SP. Po 24 godzinach od wykonania zabiegu stwierdzono skuteczność na poziomie 93\%, przy czym po 5 dniach była ona nadal wysoka - około $95 \%$ w przypadku obu środków. Równie skuteczny był olejek otrzymany z alfazemy (Hyptis suaveolens L.), rośliny zwanej amerykańską miętą, rosnącej w północno-wschodniej części Brazylii (Abramson i wsp. 2006). Po zastosowaniu go w 1\% stężeniu śmiertelność mszyc wyniosła około $95 \%$ już po 4 godzinach od aplikacji, natomiast po zastosowaniu olejku citronelowego (Cymbopogon winterianus) skuteczność była mniejsza, tj. 81\%. Bardzo ciekawym dodatkowym efektem olejku z alfazemy jest działanie wabiące biedronki (Cycloneda sanguinea L.), które są naturalnymi wrogami mszyc. Isik i Görür (2009) prowadząc badania nad ograniczeniem liczebności mszycy kapuścianej (Brevicoryne brassicae L.), która jest wektorem wielu wirusów m.in. na warzywach kapustnych, oceniali wpływ olejku jałowcowego (Juniperus excelsa), z kopru włoskiego (Foeniculum vulgare) i z wawrzynu szlachetnego (Laurus nobilis). Zaobserwowali oni, że działały one owadobójczo już w dawce $1 \mu \mathrm{l}$, przy czym były to badania ściśle laboratoryjne, trudne do wykorzystania w praktyce.

Poszukując źródeł działania różnych olejków na szkodniki Isman (2000) przeanalizował działanie 6 związków, występujących w olejkach eterycznych. Były to: eugenol (główny składnik m.in. goździka i cynamonu), karwakrol (występujący m.in. w tymianku, macierzance, lebiodce, kminku, oregano), citronellal (m.in. w trawie cytrynowej), tymol (m.in. w tymianku i oregano), terpineol (w olejku muszkatołowym i pomarańczowym), anetol (w olejku anyżowym). Okazało się, że na gąsienicę tytoniową (Spodoptera litura) największe działanie toksyczne miał: eugenol, terpineol, citrolellal.

$\mathrm{Na}$ rynku istnieje wiele olejków eterycznych lub mieszanin ze związków składowych. Jednym z nich jest EcoSMART (mieszanina eugenolu, tymolu i propionianu fenetylu). Badano jego skuteczność w zwalczaniu mszyc M. persicae, stosując stężenie od 0,18 do $0,9 \%$. Po 24 godzinach śmiertelność mszyc wynosiła od 22 do $86 \%$ (na obiektach kontrolnych około 10\%), natomiast 24 godziny później $60-100 \%$. W tym samym czasie na obiektach bez ochrony redukcja wyniosła jedynie około 13\% (Isman 2000).

Monoterpen - pulegon to naturalnie występujący w tkankach roślinnych semiozwiązek, który można znaleźć w olejkach eterycznych roślin z rodzaju Mentha. Semiozwiązki działaja modyfikująco na zachowanie, wzrost i rozwój roślinożernych owadów (Daferera i wsp. 2003). Dancewicz i wsp. (2008) zbadali działanie repelentne tego związku na $M$. persicae. Na liściach kapusty pekińskiej (Brassica pekinensis) traktowanych R-(+)- pulegonem, odnotowano istotne ograniczenie penetracji tkanek pozafloemowych przez mszycę $M$. persicae oraz wydłużanie czasu penetracji, co wskazuje na odstraszające działanie tego związku w obrębie tkanek roślinnych.

W 2009 roku Dancewicz i wsp. (2009) zbadali kolejny semiozwiązek wobec mszycy brzoskwiniowej na liściu kapusty pekińskiej. Efekt działania deterentnego benzoksepanonu, występował od pierwszej godziny po zastosowaniu substancji i trwał co najmniej 24 godziny.

\section{Dalsze przykłady zastosowań olejków Further application of using essentials oils}

Szkodnikami, do walki z którymi próbuje się wykorzystać olejki eteryczne, są także wciornastki i przędziorki. Wciornastki to szkodniki, których szkodliwość jest obserwowana zarówno jesienią, jak i wiosną. Spośród warzyw najczęściej występują na cebuli i warzywach kapustnych. Osobniki dorosłe i larwy wysysają soki ze szczypioru, czego efektem są srebrzyste plamki na jego powierzchni, a następnie deformacja rośliny. Szkodnik ten opanowuje cebulę, kiedy znajduje się ona już w fazie 3-5 liści (http://www.uprawyekologiczne.pl/346_Wciornastek_tyto niowiec.html). W 2002 roku Koshier i wsp. (2002) stwierdzili ograniczające działania olejku majerankowego, lawendowego, miętowego oraz rozmarynowego na liściach pora. W następnych latach przebadali kolejne olejki - rozmarynowy i majerankowy (Koshier i Sedy 2003). W stężeniu $1 \%$ olejek rozmarynowy wykazał większą repelencję od olejku majerankowego, zaobserwowaną już po 6 godzinach od aplikacji. W przypadku przędziorka chmielowca (Tetranychus urticae Koch), występującego na fasoli karłowatej w badaniach Górskiego i Piątek (2008), stwierdzono $100 \%$ śmiertelność szkodnika po zastosowaniu olejku $\mathrm{z}$ mięty pieprzowej i geraniowego w stężeniach: 0,$2 ; 0,05 ; 0,1 \%$ oraz tymiankowego w koncentracji: 0,$05 ; 0,1 \%$ i lawendowego - 0,02 i $0,05 \%$ po 72 godzinach od aplikacji (Górski i Tomczak 2010).

Ziemiórki (Sciaridae), w odróżnieniu od muszek owocowych nie interesują się owocami tylko wilgotną ziemią w doniczkach. Dorosłe owady nie są niebezpieczne dla roślin. Problem stanowią larwy żyjące w glebie, które podgryzają tworzące się młode korzenie roślin. Larwy ziemiórek uszkadzają również kiełkujące siewki i nasiona (http://www.poradnikogrodnika.pl/index.php?option=com content $\&$ view $=$ category\&layout $=$ blog $\& \mathrm{id}=48 \&$ Itemid $=1$ 77\&limitstart=7). Górski (2004, 2005) zastosował niebieskie i żółte tablice chwytne w monitorowaniu tego szkodnika z umieszczeniem na nich odpowiednich olejków eterycznych. Rośliną testową był pomidor, silnie zaatakowany przez ziemiórki. Górski (2004) stwierdził wysoką efektywność olejku świerkowego, zastosowanego na 
Tabela 1. Przykłady zastosowań olejków eterycznych w rolnictwie

Table 1. The examples of used essentials oils in agricultural

\begin{tabular}{|c|c|c|c|}
\hline $\begin{array}{l}\text { Olejek eteryczny } \\
\text { Essential oil }\end{array}$ & $\begin{array}{l}\text { Materiał roślinny } \\
\text { Plant material }\end{array}$ & $\begin{array}{l}\text { Materiał badany } \\
\text { Pest insects }\end{array}$ & $\begin{array}{l}\text { Skuteczność } \\
\text { Effectivness }\end{array}$ \\
\hline 1 & 2 & 3 & 4 \\
\hline $\begin{array}{l}\text { Rozmarynowy - Rosemary oil } \\
\text { Tymiankowy - Thyme oil } \\
\text { Mięta pieprzowa } \\
\text { Pepermint oil } \\
\text { Lawendowy - Lavender oil } \\
\text { Z mięty polnej - Spermint oil }\end{array}$ & $\begin{array}{c}\text { rośliny z rodziny } \\
\text { wargowych (Labiatae) } \\
\text { Labiatae plants }\end{array}$ & $\begin{array}{l}\text { mszyca brzoskwiniowa } \\
\text { peach potato aphid } \\
\text { Myzus persicae }\end{array}$ & $\begin{array}{l}\text { działanie deterentne na mszyce, } \\
\text { wysoka aktywność deterentna } \\
\text { deterring aphids, high activities }\end{array}$ \\
\hline $\begin{array}{l}\text { Rozmarynowy - Rosemary oil } \\
\text { Imbirowy - Ginger oil }\end{array}$ & $\begin{array}{l}\text { tytoń } \\
\text { tobacco }\end{array}$ & $\begin{array}{c}\text { mszyca brzoskwiniowa } \\
\text { Myzus persicae } \\
\text { poletko otoczono: } \\
\text { testing field was encircle: } \\
\text { - sznurkiem - rope } \\
\text { - kulkami EVA - marble EVA }\end{array}$ & $\begin{array}{l}37 \% \text { mniej mszyc od kontroli, } \\
37 \% \text { less aphids then control } \\
31 \% \text { mniej mszyc od kontroli, } \\
31 \% \text { less aphids then coontrol, } \\
\text { mniejsze działanie na dużych areałach } \\
\text { lowest effect on testing field }\end{array}$ \\
\hline $\begin{array}{l}\text { Komosa piżmowa } \\
\text { w stężeniu } 0,5 \% \\
\text { Chenopodium ambrosioides } \\
\text { oil in concetration } 0.5 \%\end{array}$ & $\begin{array}{l}\text { komosa piżmowa } \\
\text { Chenopodium } \\
\text { ambrosioides }\end{array}$ & $\begin{array}{l}\text { mszyca brzoskwiniowa } \\
\text { Myzus persicae }\end{array}$ & $\begin{array}{l}43 \% \text { po } 24 \mathrm{~h} \text {, skuteczność większa od mydła } \\
\text { szarego, oleju NEEM (miodla indyjska), } \\
\text { endosulfanu } \\
43 \% \text { after } 24 \mathrm{~h} \text {, effectiveness was higher then } \\
\text { soap and NEEM oil and endosulfan }\end{array}$ \\
\hline $\begin{array}{l}\text { Z kopru włoskiego } \\
\text { Fennel oil } \\
\text { Anyżowy - Anise oil } \\
\text { Bazyliowy - Basil oil }\end{array}$ & $\begin{array}{l}\text { koper włoski } \\
\text { fennel } \\
\text { anyż - anise } \\
\text { bazylia - basil }\end{array}$ & $\begin{array}{l}\text { mszyca brzoskwiniowa } \\
\text { Myzus persicae } \\
\text { mszyca grochowianka } \\
\text { Acyrthosiphon pisum }\end{array}$ & $\begin{array}{l}\text { z } 12 \text { olejków } 3 \text { były skuteczne, } \\
\text { śmiertelność duża } \\
\text { from } 12 \text { oils } 3 \text { was effective, mortality higher }\end{array}$ \\
\hline $\begin{array}{l}\text { Geraniowy - Geranium oil } \\
\text { Lawendowy - Lavender oil } \\
\text { Mięta pieprzowa } \\
\text { Pepermint oil } \\
\text { Sosnowy - Pine oil } \\
\text { Tymiankowy - Thyme oil }\end{array}$ & $\begin{array}{l}\text { tytoń } \\
\text { tobacco }\end{array}$ & \begin{tabular}{|c|} 
mszyca ziemniaczana \\
Acyrthosiphon solani \\
zanurzano liście razem z mszycami \\
w roztworze z olejkiem przez 3 \\
sekundy \\
leaf of eggplant with aphids was \\
deep in oil for 3 second
\end{tabular} & $\begin{array}{l}\text { stężenie/śmiertelność - concentration/mortality } \\
0,05 \% \text { po } 24 \text { h } 100 \%-0.05 \% \text { after } 24 \text { h } 100 \% \\
0,02 \% \text { po } 24 \text { h } 100 \%-0.02 \% \text { after } 24 \text { h } 100 \% \\
0,05 \% \text { po } 24 \text { h } 100 \%-0.05 \text { after } 24 \text { h } 100 \% \\
0,1 \% \text { po } 24 \text { h } 100 \%-0.1 \% \text { after } 24 \text { h } 100 \% \\
0,1 \% \text { po } 48 \text { h } 100 \%-0.1 \% \text { after } 48 \text { h } 100 \%\end{array}$ \\
\hline $\begin{array}{l}\text { Kolendrowy-Coriander oil } \\
\text { Petitgrain - Petitgrain oil }\end{array}$ & $\begin{array}{l}\text { tytoń } \\
\text { tobacco }\end{array}$ & \begin{tabular}{|l|} 
mszyca ziemniaczana \\
Acyrthosiphon solani
\end{tabular} & $\begin{array}{l}81,2-99,5 \% \text { po } 72 \mathrm{~h}-81.2-99.5 \% \text { after } 72 \mathrm{~h} \\
89,8-99,5 \% \text { po } 72 \mathrm{~h}-89.8-99.5 \% \text { after } 72 \mathrm{~h}\end{array}$ \\
\hline $\begin{array}{l}\text { Cytronelowy - Citronella oil } \\
\text { Paczulowy - Patchouli oil } \\
\text { Jałowcowy - Juniper oil } \\
\text { Bazyliowy - Basil oil } \\
\text { Eukaliptusowy - Eucalyptus oil }\end{array}$ & $\begin{array}{l}\text { oberżyna } \\
\text { eggplant }\end{array}$ & $\begin{array}{c}\text { mszyca ziemniaczana } \\
\text { Acyrthosiphon solani } \\
\text { zanurzano liście razem } \\
\text { z mszycami w roztworze } \\
\text { z olejkiem przez } 3 \text { sekundy } \\
\text { leaf of eggplant with aphids was } \\
\text { deep in oil for } 3 \text { second }\end{array}$ & $\begin{array}{l}\text { stężenie/śmiertelność - concentration/mortality } \\
0,05 \text { i } 0,1 \% \text { w } 100 \%-0.05 \text { and } 0.1 \% \text { in } 100 \% \\
0,05 \text { i } 0,1 \% \text { w } 100 \%-0.05 \text { and } 0.1 \% \text { in } 100 \% \\
0,1 \% \text { w } 100 \%-0.1 \% \text { on } 100 \% \\
\text { niska skuteczność }- \text { low effective } \\
(50 \% \text { po } 72 \text { h) }-(50 \% \text { after } 72 \text { h) }\end{array}$ \\
\hline Eukaliptusowy - Eucalyptus oil & $\begin{array}{l}\text { szalka Petriego } \\
\text { bibułka moczona } \\
\text { Petrii dish }\end{array}$ & $\begin{array}{l}\text { mszyca ogórkowa } \\
\text { Aphis gossypii }\end{array}$ & $\begin{array}{l}55-100 \% \text { w pierwszej godzinie } \\
55-100 \% \text { in one hour } \\
84-100 \% \text { po } 24 \mathrm{~h} \\
84-100 \% \text { after } 24 \mathrm{~h}\end{array}$ \\
\hline $\begin{array}{l}\text { Kolendra - Coriander oil } \\
\text { Eukaliptus - Eucalyptus oil }\end{array}$ & $\begin{array}{l}\text { bulwy ziemniaków } \\
\text { potato tubers }\end{array}$ & $\begin{array}{l}\text { działanie na kiełki } \\
\text { effect on sprouts }\end{array}$ & $\begin{array}{l}20 \% \text { wykiełkowało po } 60 \text { dniach } \\
20 \% \text { sprouted after } 60 \text { days } \\
5 \% \text { wykiełkowało po } 60 \text { dniach } \\
5 \% \text { sprouted after } 60 \text { days } \\
\text { kontrola } 100 \% \text { - control } 100 \%\end{array}$ \\
\hline $\begin{array}{l}\text { Z konopi siewnej } \\
\text { Hemp oil }\end{array}$ & $\begin{array}{l}\text { jabłoń } \\
\text { apple tree }\end{array}$ & $\begin{array}{c}\text { mszyca jabłoniowo-babkowa } \\
\text { Dysaphis plantaginea Pass. } \\
\text { oprysk gałęzi } \\
\text { spray branches } \\
\end{array}$ & $\begin{array}{l}0,02-80 \% \text { po } 24 \mathrm{~h}-0.02-80 \% \text { after } 24 \mathrm{~h} \\
0,05-93 \% \text { po } 24 \mathrm{~h}-0.05-93 \% \text { after } 24 \mathrm{~h} \\
0,1-93 \% \text { po } 24 \mathrm{~h}-0.1-93 \% \text { after } 24 \mathrm{~h}\end{array}$ \\
\hline $\begin{array}{l}\text { Citronela - Citronella } \\
\text { Alfazema - Alfazema }\end{array}$ & $\begin{array}{l}\text { łodyga koprowa } \\
\text { fennel stalk }\end{array}$ & $\begin{array}{c}\text { mszyca koprowa } \\
\text { Hyadaphis foeniculi Pass. } \\
\text { biedronka } \\
\text { Cycloneda sanguinea L. }\end{array}$ & $\begin{array}{l}80 \% \text { po } 5 \mathrm{~h}-80 \% \text { after } 5 \mathrm{~h} \\
98 \% \text { po } 4 \mathrm{~h} \text { jest mocniejsza i działa wabiąco na } \\
\text { biedronki - } 98 \% \text { after } 4 \mathrm{~h} \text { attractive to ladybug }\end{array}$ \\
\hline $\begin{array}{l}\text { Jałowcowy - Juniper oil } \\
\text { Z kopru włoskiego - Fennel oil } \\
\text { Wawrzyn szlachetny - Laurel } \\
\text { noble }\end{array}$ & $\begin{array}{l}\text { kapusta } \\
\text { cabbage }\end{array}$ & $\begin{array}{c}\text { mszyca kapuścianka Brevicoryne } \\
\text { brassicae L. }\end{array}$ & $\begin{array}{l}\text { działanie owadobójcze już w dawce } 1 \mu \mathrm{l} \\
\text { insecticidal activity already at a dose of } 1 \mu \mathrm{l}\end{array}$ \\
\hline
\end{tabular}




\begin{tabular}{|c|c|c|c|}
\hline 1 & 2 & 3 & 4 \\
\hline $\begin{array}{l}\text { Eugenol (goździk, cynamon) } \\
\text { Eugenol (carnation, cinnamon) } \\
\text { Tymol (tymianek, oregano) } \\
\text { Tymol (thyme, oregano) } \\
\text { Karwakrol (oregano, kminek, } \\
\text { tymianek) } \\
\text { Carvacrol (oregano, cumin, } \\
\text { thyme) } \\
\text { Terpineol (w olejku } \\
\text { muszkatołowym } \\
\text { i pomarańczowym) } \\
\text { Terpineol (in nutmegand and } \\
\text { orange oil) } \\
\text { Citronellal (w trawie } \\
\text { cytrynowej) } \\
\text { Citronellal (in lemon grass) } \\
\text { Anetol (w olejku anyżowym) } \\
\text { Anethole (in anise oil) }\end{array}$ & $\begin{array}{l}\text { liście kapusty } \\
\text { cabbage leafs }\end{array}$ & $\begin{array}{l}\text { gąsienica tytoniowa } \\
\text { Spodoptera litura }\end{array}$ & $\begin{array}{l}150 \mu \mathrm{g} \mathrm{cm}^{2} \\
\text { efektywne działanie eugenolu i jest mało } \\
\text { toksyczny } \\
\text { eugenol was the most effective and it is the } \\
\text { smallest toxic }\end{array}$ \\
\hline $\begin{array}{l}\text { EcoSMART (mieszanina } \\
\text { eugenolu, tymolu, propionianu } \\
\text { fen etylu) } \\
\text { EcoSMART }\end{array}$ & $\begin{array}{l}\text { liście kapusty } \\
\text { cabbage leafs }\end{array}$ & $\begin{array}{c}\text { mszyca brzoskwiniowa } \\
\text { Myzus persicae }\end{array}$ & $\begin{array}{l}\text { po } 24 \mathrm{~h} \text { śmiertelność od } 22 \text { do } 86 \% \\
\text { after } 24 \mathrm{~h} \text { mortality was from } 22 \% \text { to } 86 \% \\
\text { po } 48 \mathrm{~h} \text { od } 60 \text { do } 100 \% \\
\text { after } 48 \mathrm{~h} \text { from } 60 \text { to } 100 \%\end{array}$ \\
\hline $\begin{array}{l}\text { Pulegon - semiozwiązek } \\
\text { w olejkach z rodzaju Mentha } \\
\text { Pulegone } \\
\text { Benzoksepanon } \\
\text { Benzoxepionone }\end{array}$ & $\begin{array}{l}\text { kapusta pekińska } \\
\text { Peking cabbage }\end{array}$ & $\begin{array}{c}\text { mszyca brzoskwiniowa } \\
\text { Myzus persicae }\end{array}$ & $\begin{array}{l}\text { działanie odstraszające } \\
\text { repelent effect }\end{array}$ \\
\hline $\begin{array}{l}\text { Majerankowy - Marjoram oil } \\
\text { Rozmarynowy - Rosemary oil } \\
\text { Szałwiowy - Sage oil } \\
\text { Lawendowy - Lavender oil } \\
\text { Miętowy - Mint oil }\end{array}$ & $\begin{array}{l}\text { por } \\
\text { leek }\end{array}$ & $\begin{array}{l}\text { wciornastek cebuli } \\
\text { Thrips tabaci } \\
\text { olfaktometr } \\
\text { olfactometr }\end{array}$ & $\begin{array}{l}0,1-54 \% ; 10-60 \%-0.1-54 \% ; 10-60 \% \\
0,1-49 \% ; 10-77 \%-0.1-49 \% ; 10-77 \% \\
0,1-52 \% ; 10-58 \%-0.1-52 \% ; 10-58 \% \\
0,1-50 \% ; 10-46 \%-0.1-50 \% ; 10-46 \% \\
0,1-56 \% ; 10-52 \%-0.1-56 \% ; 10-52 \% \\
\end{array}$ \\
\hline $\begin{array}{l}\text { Majerankowy } 1 \% \\
\text { Marjoram oil } \\
\text { Rozmarynowy } 1 \% \\
\text { Rosemary oil } \\
\text { Szałwiowy } 1 \% \text { - Sage oil } \\
\text { Lawendowy } 1 \% \text { - Lavender oil } \\
\text { Miętowy } 1 \% \\
\text { + Triton X-100 }(0,5 \%) \\
\text { - utrzymuje wilgoć } \\
\text { Mint oil } \\
\text { + Triton X-100 }(0.5 \%) \\
\text { - hold moisture }\end{array}$ & $\begin{array}{l}\text { por } \\
\text { leek }\end{array}$ & \begin{tabular}{|c|} 
wciornastek cebuli \\
Thrips tabaci \\
szalka Petriego i liść zamoczony w \\
roztworze olejku; \\
odczyt po 15 minutach, \\
$1,2,4$ i $6 \mathrm{~h}$ \\
Petri dish, leafs was deeping \\
in oil; \\
results after 15 minutes, \\
$1,2,4$ and $6 \mathrm{~h}$
\end{tabular} & $\begin{array}{l}\text { dość skuteczny - guite effective } \\
\text { bardzo skuteczny - effective } \\
\text { mało skuteczny - not so effective } \\
\text { mało skuteczny - not so effective } \\
\text { mało skuteczny - not so effective }\end{array}$ \\
\hline $\begin{array}{l}\text { Geraniowy - Geranium oil } \\
\text { Lawendowy - Lavender oil } \\
\text { Mięta pieprzowa - Pepermint } \\
\text { oil } \\
\text { Sosnowy - Pine oil } \\
\text { Tymiankowy - Thyme oil }\end{array}$ & $\begin{array}{l}\text { fasola karłowa } \\
\text { dwarf bean }\end{array}$ & $\begin{array}{l}\text { przędziorek chmielowiec } \\
\text { Tetranychus urticae }\end{array}$ & $\begin{array}{l}\text { stężenie olejku i skuteczność } \\
\text { concentration and mortality } \\
0,02 \% \text { po } 24 \text { h } 100 \%-0.02 \% \text { after } 24 \text { h } 100 \% \\
0,02 \% \text { po } 24 \text { h } 100 \%-0.02 \% \text { after } 24 \text { h } 100 \% \\
0,02 \% \text { po } 24 \text { h } 100 \%-0.02 \% \text { after } 24 \text { h } 100 \% \\
0,1 \% \text { po } 72 \text { h } 99 \%-0.1 \% \text { after } 72 \text { h } 99 \% \\
0,05 \% \text { po } 24 \text { h } 100 \%-0.05 \% \text { after } 24 \text { h } 100 \%\end{array}$ \\
\hline $\begin{array}{l}\text { Świerkowy - Spruce oil } \\
Z \text { drzewa herbacianego } \\
\text { Tee Tree oil }\end{array}$ & $\begin{array}{l}\text { pomidor - tomato } \\
\text { niebieskie tablice } \\
\text { chwytne } \\
\text { the blue sticky traps }\end{array}$ & $\begin{array}{l}\text { ziemiórki } \\
\text { Sciaridae }\end{array}$ & $\begin{array}{l}\text { efektywność }-61 \% \text { - effectiveness }-61 \% \\
\text { efektywność }-25,3 \% \text { - effectiveness }-25.3 \%\end{array}$ \\
\hline $\begin{array}{l}\text { Imbirowy - Ginger oil } \\
\text { Tatarakowy - Sweet flag oil }\end{array}$ & $\begin{array}{l}\text { pomidor - tomato } \\
\text { źółte tablice chwytne } \\
\text { the yellow sticy traps }\end{array}$ & $\begin{array}{l}\text { ziemiórki } \\
\text { Sciaridae }\end{array}$ & $\begin{array}{l}50 \% \text { mniej złapanych owadów od kontroli } \\
50 \% \text { less caught insects from the control } \\
44 \% \text { mniej złapanych owadów od kontroli } \\
44 \% \text { less cought insect from the control }\end{array}$ \\
\hline $\begin{array}{l}\text { Wyciag z czosnku } \\
\text { (Bioczos BR) } \\
\text { Extract of garlic (Bioczos BR) }\end{array}$ & $\begin{array}{l}\text { groch } \\
\text { tansy }\end{array}$ & $\begin{array}{l}\text { chrząszcze oprzędzików } \\
\text { Sitona spp. }\end{array}$ & $\begin{array}{l}\text { uszkodzenie }-18 \% \\
\text { damage }-18 \%\end{array}$ \\
\hline
\end{tabular}




\begin{tabular}{|c|c|c|c|}
\hline 1 & 2 & 3 & 4 \\
\hline $\begin{array}{l}\text { Wyciag z czosnku } \\
\text { Extract of garlic } \\
\text { Ekstrakt z wrotyczu } \\
\text { pospolitego } \\
\text { Tansy extract } \\
\text { Piołun - Wormwood } \\
\text { Mydło potasowe - Soap }\end{array}$ & $\begin{array}{l}\text { liście } \\
\text { leaf }\end{array}$ & $\begin{array}{c}\text { mszyca brzoskwiniowa } \\
\text { Myzus persicae }\end{array}$ & $\begin{array}{l}\text { najsilniejsze działanie repelentne wykazał } \\
\text { Bioczos } \\
\text { Forte w połączeniu z mydłem potasowym oraz } \\
\text { mieszanina ekstraktów z wrotyczu } 1 \% \text {, piołunu } \\
1 \% \\
+ \text { mydło } \\
\text { the strongest detterent effect was Bioczos Forte } \\
+ \text { soap and tansy extract } 1 \%+\text { wormwood } 1 \% \\
+ \text { soap }\end{array}$ \\
\hline
\end{tabular}

niebieskich tablicach chwytnych. Liczba odłowionych owadów wzrosła o $61 \% \mathrm{w}$ stosunku do kontroli, gdzie nie stosowano olejków. Inny olejek $\mathrm{z}$ drzewa herbacianego silnie przyciagał ziemiórki. Jednak jego efektywność wyniosła tylko $25,3 \%$. Działanie odstraszające olejku imbirowego na żółtych tablicach chwytnych wyniosło $53,3 \%$ w odniesieniu do kontroli bez ochrony, a olejku tatarakowego w $44 \%$.

\section{Naturalne metody ochrony Natural methods use in plant protection}

Jeszcze przed kilkudziesięciu laty do podstawowych insektycydów stosowanych w rolnictwie należały odwary i napary $\mathrm{z}$ tytoniu. Zawarta $\mathrm{w}$ nich nikotyna skutecznie zwalczała mszyce i inne owady. Wysoka toksyczność tego alkaloidu dla organizmów stałocieplnych, a także kłopotliwe przygotowanie cieczy użytkowe sprawiły, że obecnie preparaty tytoniowe są stosowane sporadycznie, głównie przez działkowców. O wielu innych zastosowaniach preparatów roślinnych w ekologicznej ochronie przed szkodnikami szerzej pisała Wasina (1987).

Obecnie największe znaczenie w ochronie roślin przed chorobami spośród preparatów roślinnych ma czosnek. Ekstrakty i niektóre związki izolowane $\mathrm{z}$ tej rośliny charakteryzują się wysokim spektrum działania. Antybiotyczną aktywność czosnku przypisuje się obecności allicyny. Działanie wyciągu $\mathrm{z}$ czosnku na oprzędziki w uprawie grochu siewnego wykazali Wenda-Piesik i Piesik (2009). Komercyjny preparat z wyciagu czosnkowego (Bioczos BR) skutecznie chronił rośliny grochu przed żerowaniem chrząszczy oprzędzików. Uszkodzenie grochu wyniosło około $18 \%$, a w kontroli bez ochrony $-46 \%$.

Dancewicz i Gabryś (2008) testowali działanie wyciąu z czosnku na mszycę brzoskwiniową (którzy łączyli go z ekstraktem z wrotyczu pospolitego (Tanaceum vulgare) i piołunu (Artemisia absinthium) z roztworem potasowego mydła ogrodniczego. Najsilniejsze działanie repelentne na $M$. persicae wykazywał komercyjny preparat czosnkowy Bioczos Forte w połączeniu z mydłem potasowym.

\section{Podsumowanie / Summation}

W nowoczesnej ochronie roślin rośnie zainteresowanie preparatami pochodzenia roślinnego. Ich przyjazne dla środowiska zastosowanie możemy wykorzystać jako naturalne biopestycydy, ograniczając porażenie roślin. Obiecujące są badania nad zastosowaniem naturalnych olejków eterycznych w ochronie roślin, tym bardziej, że są one uznawane za nieszkodliwe i nietoksyczne (Isman 1999, 2000). Szacuje się, że na kuli ziemskiej występuje 18 tysięcy olejkodajnych gatunków roślin. Na skalę przemysłową produkuje się około 300 olejków eterycznych (Lis i Góra 2007). Sięgając po naturalne olejki eteryczne, ekstrakty czy wyciąi roślinne, można skutecznie ograniczyć stosowanie syntetycznych substancji chemicznych. Ich właściwości zapachowe i terapeutyczne mają zastosowanie również $\mathrm{w}$ medycynie, aromaterapii, przemyśle farmaceutycznym, perfumeryjno-kosmetycznym i spożywczym. W uprawach ekologicznych wciąż brakuje badań tych niedocenionych substancji zapachowych.

\section{Literatura / References}

Abramson C.I., Wanderley P.A., Wanderley M.J., Mina A.J.S., Baracho de Souza O. 2006. Effect of essential oil from citronella and alfazema on fennel aphids Hyadaphis foeniculi Passerini (Hemiptera: Aphididae) and its predator - Cycloneda sanguine L. (Coleotera: Coccinelidae). Am. J. Environ. Sci. 3 (1): 9-10.

American bee emergency - act now 2011. AVAAZ.org, https://secure.avaaz.org/en/save_the_bees_usa/?cl=895629409\&v=8117, accessed: 21.01.2011.

Branford S. 2004. Argentina's bitter harvest (what GM soya has done for Argentina). „New Scientist”, 17 April 2004: 40-43.

Brud S., Konopacka I. 1994. Pachnąca Apteka. Tajemnice Aromatoterapii. Agencja Wyd. „Comes”, Warszawa, 152 ss.

Chiasson H., Vincent C., Bostanian N.J. 2004. Insecticidal properties of Chenopodium - based botanical. J. Econ. Entomol. 97 (4): $1378-1383$.

Cummins J. 2007. Parasitic fungi and pesticides act synergistically to kill honeybees? Science in Society 35, p. 38.

Daferera D.J., Ziogas B.N., Polissiou M.G. 2003. The effectiveness of plant essentials oils on the growth of Botrytis cinerea, Fusarium sp. and Clavibacter michiganensis subsp. michiganensis. Crop Prot. 22 (1): 39-44. 
Dancewicz K., Gabryś B. 2008. Wpływ ekstraktów z czosnku Allium sativum, piołunu Artemisia absinthium i wrotyczu Tanaceum vulgare na zachowanie mszycy brzoskwiniowej Myzus persicae (Sulz.) podczas zasiedlenia roślin. Pestycydy/Pesticides 3-4: 93-99.

Dancewicz K., Gabryś B., Dams I., Wawrzeńczyk Cz. 2008. Wpływ pulegonu i jego syntetycznych pochodnych na wczesne reakcje mszycy brzoskwiniowej (Myzus persicae Sulzer) w czasie zasiedlania i penetracji roślin. Prog. Plant Prot./Post. Ochr. Roślin 48 (3): 819-820.

Dancewicz K., Gabryś B., Masłowiec D., Gliszczyńska A., Wawrzeńczyk Cz. 2009. Wpływ pochodnych benzoksypanonu na zasiedlanie roślin przez mszycę brzoskwiniową (Myzus persicae Sulzer). Prog. Plant Prot./Post. Ochr. Roślin 49 (3): $1175-1178$.

Digilioa M.C., Mancini E., Voto E., de Foe V. 2008. Insecticidae activity of Mediterranean essencial oils. J. Plant Interactions 3: 17-23.

Górski R. 2004. Skuteczność naturalnych olejków eterycznych zastosowanych na żółtych tablicach chwytnych w monitorowaniu ziemiórek (Sciaridae). Rocz. AR Poznań 36: 43-48.

Górski R. 2005. Skuteczność naturalnych olejków eterycznych zastosowanych na niebieskich tablicach chwytnych w monitorowaniu ziemiórek (Sciaridae). Rocz. AR Poznań 37: 27-32.

Górski R., Kania A. 2010. Wpływ olejków kolendrowego i petitgrain na śmiertelność mszycy ziemniaczanej (Aulacorthum solani Kalt.) występującej na tytoniu. Prog. Plant Prot./Post. Ochr. Roślin 50 (3): 1529-1532.

Górski R., Piątek H. 2008. Skuteczność działania naturalnych olejków eterycznych w zwalczaniu przędziorka chmielowca (Tetranychus urticae Koch) występującego na fasoli karłowej. Prog. Plant Prot./Post. Ochr. Roślin 48 (4): 1347-1350.

Górski R., Piątek H. 2009. Wpływ naturalnych olejków eterycznych na śmiertelność mszycy ziemniaczanej (Aulacorthum solani Kalt.) występującej na tytoniu szlachetnym. Prog. Plant Prot./Post. Ochr. Roślin 49 (4): 2009-2012.

Górski R., Szklarz M., Kaniewski R. 2009. Skuteczność olejku eterycznego z konopi siewnej w zwalczaniu mszycy jabłoniowobabkowej (Dysaphis plantaginea Pass.) występującej na jabłoni. Prog. Plant Prot./Post. Ochr. Roślin 49 (4): 2013-2016.

Górski R., Tomczak M. 2010. Przydatność naturalnych olejków eterycznych w zwalczaniu mszycy ziemniaczanej (Aulacorthum solani Kalt.) występującej na oberżynie (Solanum melongena L.). Ecol. Chem. Eng. 17 (3): 345-349.

Hori M. 1998. Repellency of rosemary oil against Myzus persicae in a laboratory and in a screenhouse. J. Chem. Ecol. 24 (9): $1425-1432$.

Hori M. 1999. The effects of rosemary and ginger oils on the alighting behavior of Myzus persicae (Sulzer) (Homoptera: Aphidae) and on the incidence of yellow spotted streak. Appl. Entomol. Zool. 34 (3): 351-358.

http://www.uprawyekologiczne.pl/346_Wciornastek_tytoniowiec.html

http://www.poradnikogrodnika.pl/index.php?option=com_content\&view=category\&layout=blog\&id=48\&Itemid=177\&limitstart=7

Isik M., Görür G. 2009. Aphidicidial activity of seven essentials oils against the cabbage aphid, Brevicoryne brassicae L. (Hemiptera: Aphididae). Mun. Ent. Zool. 4 (2): 424-431.

Isman M.B. 1999. Pesticides based on plant essential oils. Pestic. Outlock 9: 68-72.

Isman M.B. 2000. Plant essentials oils for pest and disease management. Crop Prot. 19: 603-608.

Koschier E.H., Sedy K.A. 2003. Labiate essential oils affecting host selection and acceptance of Thrips tabaci Lindeman. Crop Prot. 22: 929-934.

Koschier E.H., Sedy K.A., Novak J. 2002. Influence of plant volatiles on feeding damage caused by the onion thrips Thrips tabaci. Crop Prot. 21: 419-425.

Lis A., Góra J. 2007. Najcenniejsze Olejki Eteryczne. Uniwersytet Mikołaja Kopernika, Toruń, 2007, 5: 81-8, 106-11, 241-51.

Mareggiani G., Russo S., Rocca M. 2008. Eucaliptus globulus (Mirtaceae) essential oil: efficacy against Aphis gossygpii (Hemiptera: Aphidae), and agricultural pest. Ev. Latinoamer. Quim. 36/1: 16-21.

Matyjaszczyk E. 2009. Zmiany w możliwościach ochrony ziemniaka. Ziemniak Polski 4: 29-33.

Ożarowski A., Jaroniewski W. 1987. Rośliny Lecznicze i ich Praktyczne Zastosowanie. Instytut Wydawniczy Związków Zawodowych, Warszawa, 436 ss.

Regnault R. 1997. The potential of botanical essential oils for insect pest control. J. IPM Rev. 2 (1): 25-34.

Tunc I., Sahinkaya S. 1998. Sensitivity of two greenhouse pests to vapours of essential oils. Entomol. Exp. Appl. 86: $183-187$.

Wasina A. 1987. Wykorzystanie Roślin do Zwalczania Szkodników w Sadach i Ogrodach. PWRiL, Warszawa, 80 ss.

Wenda-Piesik A., Piesik D. 2009. Skuteczność wyciagu z czosnku w ograniczaniu oprzędzików (Sitona spp.) w uprawie grochu siewnego. Prog. Plant Prot./Post. Ochr. Roślin 49 (4): 2038-2043. 